\author{
ADAM KORCZYŃSKI \\ Polska Akademia Umiejętności \\ (D) https://orcid.org/0000-0003-4802-213X
}

\title{
DOKUMENTACJA FOTOGRAFICZNA KOŚCIOŁA ŚWIĘTEJ KATARZYNY W KRAKOWIE W ZBIORZE FOTOGRAFII KAROLA LANCKOROŃSKIEGO ${ }^{1}$
}

Słowa kluczowe: fotografia, Kraków, Krieger, Lanckoroński, sztuka

Fototeka Lanckorońskich, przekazana Polskiej Akademii Umiejętności w roku 1929, to archiwum fotograficzne dotyczące wielu zabytków oraz dzieł sztuki². Powstałe i zgromadzone na przełomie wieków XIX i XX fotografie dokumentują ówczesny stan zachowania poszczególnych obiektów. Zbiór fotografii zgromadzonych przez Karola Lanckorońskiego ${ }^{3}$ posiada współcześnie nie tylko wartość dokumentacyjną, ale ze względu na autorstwo przechowywanych w nim zdjęć również kolekcjonerską i artystyczną.

Pośród dziewiętnastowiecznej dokumentacji fotograficznej w Fototece Lanckorońskich znajdują się także fotografie dotyczące kościoła św. Katarzyny i klasztoru augustianów na krakowskim Kazimierzu. Przedstawiają one stan kościoła po przeprowadzeniu w nim części niezbędnych prac restauracyjnych. Prowadzone etapami od roku 1852 czynności były kierowane między innymi przez architektów

1 Wszystkie opisywane w tekście fotografie dostępne są w domenie publicznej, w Katalogu zbiorów artystycznych i naukowych Polskiej Akademii Umiejętności: www.pauart.pl.

2 O historii zbioru fotografii Karola Lanckorońskiego zob.: A. Korc zy ński, Fototeka Lanckorońskich, Lanckoroniana, t. 5, Rzym 2018. Zob. też: idem, Fototeka Lanckorońskich, „Rocznik Biblioteki Naukowej PAU i PAN w Krakowie", R. 56: 2011, s. 421-442.

3 Karol Lanckoroński (1848-1933) - uczony, organizator wypraw archeologicznych, podróżnik, kolekcjoner, znawca sztuki, mecenas. Od roku 1891 członek korespondent Akademii Umiejętności. Współorganizator i członek najwyższych austriackich urzędów do spraw sztuki. Swoją działalnością przyczynił się do utworzenia na terenie monarchii habsburskiej nowoczesnej opieki nad zabytkami oraz służby konserwatorskiej. Zob. też: R. Taborski, Lanckoroński Karol z Brzezia (1848-1933), w: Polski Stownik Biograficzny (dalej: PSB), t. 16, s. 442-443. Obszerna bibliografia dotycząca Karola Lanckorońskiego znajduje się na stronie Stacji Naukowej PAN w Wiedniu: http:// www.viennapan.org/index.php?option=com_content\&view=article\&id=702\&Itemid=746\&lan$\mathrm{g}=\mathrm{pl}$ (dostęp: 02.04.2019). 
Ludwika Bejma i Karola Kremera4 ${ }^{4}$ Inicjatorami tych działań był ówczesny prowincjał zakonu Zygmunt Wołek oraz przeor Bonawentura Świętczak ${ }^{5}$. Bliższe czasowo okresowi wykonania opisywanych zdjęć były jednak prace prowadzone za przeoratu Mikołaja Szpernogi i Augustyna Sutora. Dotyczyły one głównie restauracji oraz wyposażenia wnętrza i zostały zrealizowane między innymi pod kierunkiem rzeźbiarza Edwarda Stehlika, a także architekta Karola Knausa (lata 1892-1904) ${ }^{6}$. W przypadku zabudowań klasztornych prace o charakterze remontowym i adaptacyjnym były prowadzone już w latach $1835-1865^{7}$.

Przy aktualnym stanie opracowania archiwalnego zbioru fotografii Karola Lanckorońskiego dziewiętnastowieczna dokumentacja fotograficzna dotycząca kościoła św. Katarzyny i klasztoru augustianów, a także zabytków i dzieł sztuki związanych z tymi obiektami, liczy czterdzieści siedem odbitek albuminowych ${ }^{8}$. Większość z nich sygnowana jest nazwiskiem Krieger ${ }^{9}$. Ich autorstwo należy jednak prawdopodobnie przypisać nie tylko Ignacemu Kriegerowi (1820-1889) ${ }^{10}$, który jak wiadomo fotografował m.in. krakowskie zabytki ${ }^{11}$, ale też jego synowi, Natanowi Kriegerowi (1844-1903) ${ }^{12}$.

${ }^{4}$ E. Chojecka, J. Sa mek, H. Małki ewic zówna, Kościót par. p. w. śś. Katarzyny i Matgorzaty i dawny klasztor augustianów, w: Katalog zabytków sztuki w Polsce. Miasto Kraków. Kazimierz i Stradom. Kościoły i klasztory, red. I. Rejduch-Samkowa i J. Samek, Warszawa 1987, t. 4, cz. 4,1 , s. 100 .

5 Ibidem.

${ }^{6}$ Ibidem.

7 Ibidem, s. 115.

8 W liczbie tej znajdują się również dublety zdjęć.

9 Wraz z rozpoczęciem przez Ignacego Kriegera (1860) fotograficznej działalności w Krakowie, obok dotychczasowej fotografii portretowej ówczesnych elit, pojawiać się zaczyna fotografia dokumentalna. Do tego kierunku fotografii krakowskiej poza nim zalicza się także Walery Rzewuski czy Awit Szubert. Zob. J. K o zi ń s k i, Fotografia krakowska w latach 1840-1914, Kraków 1978, s. 37. Ignacemu Kriegerowi przypisywane jest również pierwszeństwo pośród fotografów krakowskich w wyspecjalizowaniu się w fotografiach zabytków i dzieł sztuki. Zob. T. Kwiatkowska, A. Mali k, Zespót negatywów szklanych z zakładu fotograficznego rodziny Kriegerów w posiadaniu Muzeum Historycznego Miasta Krakowa, „Krzysztofory” 1984, nr 11, s. 67. O początkach Zakładu Ignacego Kriegera zob. W. M o s s k o w s k a, Topografia Zakładu Fotograficznego Ignacego Kriegera, „Krzysztofory” 1985, nr 12, s. 56-60.

${ }^{10} \mathrm{~W}$ literaturze przedmiotu najczęściej za datę urodzin Ignacego Kriegera przyjmuje się rok 1820. Zob. m.in.: C. B ą k-Ko c zar s k a, Krieger Ignacy (1820-1889), w: PSB, t. 15, s. 307-308; J. Koziński, Fotografia krakowska..., s. 104-105.

${ }^{11}$ „Po roku 1870-tym miał już [Ignacy Krieger] sfotografowaną wielką liczbę obiektów zabytkowych [...] wszystkie pomniki katedry i niektórych kościołów krakowskich...”, cyt. za: T. Kwiatkowska, A. Malik, Zespót negatywów szklanych z zakładu fotograficznego rodziny Kriegerów..., s. 52.

12 Datę roczną 1896 widać m.in. na odbitce FL.2174.9. Jerzy Koziński zauważa, że cały szereg zdjęć przypisywanych Natanowi Kriegerowi - detali architektonicznych, budowli, reprodukcji dokumentów oraz odcisków pieczęci - posiada wyretuszowane w dolnej części obrazu daty roczne 
Ten ostatni, jako członek Towarzystwa Miłośników Historii i Zabytków Krakowa $^{13}$, rozwinął współpracę zakładu z krakowskim środowiskiem historyków, historyków sztuki oraz konserwatorów ${ }^{14}$. Na ich zlecenia i pod ich kierunkiem fotografował średniowieczne dokumenty, pieczęcie i zabytkowe obiekty ${ }^{15}$. Pod kierownictwem Stanisława Krzyżanowskiego i Władysława Semkowicza pracownia Kriegerów wykonała dla Akademii Umiejętności fotografie najstarszych polskich dokumentów ${ }^{16}$. Specjalizacja w fotografowaniu dzieł sztuki, zabytków i pamiątek kultury materialnej przyniosła Natanowi Kriegerowi uznanie w kręgach artystycznych i naukowych, a także współpracę z „Rocznikiem Krakowskim”17. Zdjęcia autorstwa Ignacego i Natana Kriegerów służyły jako materiał ilustracyjny dla większości ówczesnych publikacji dotyczących Krakowa ${ }^{18}$. Do zleceniodawców Natana Kriegera zaliczało się również Grono Konserwatorów Galicji Zachodniej $^{19}$ (m.in. zdjęcia wykonywane w Bieczu, odbitki o tej tematyce znajdują się także w zbiorze fotografii Karola Lanckorońskiego ${ }^{20}$ ), Uniwersytet Jagielloński, Akademia Umiejętności, Akademia Sztuk Pięknych, muzea, wreszcie prywatni

(J. Koziński, Fotografia krakowska..., s. 107). Nie musi to być jednak data wykonania samego zdjęcia. Zob. M. Niemiec, ,Jeden obraz zastępuje 1000 stów” - szklane klisze z zakładu Ignacego Kriegera jako źródło do badań geograficzno-historycznych, w: Fotografia w czasie, czas w fotografii, red. M.A. Długosz, M. Suchodolska, Lublin 2016, s. 107-108; Data 1896 nie zawsze odpowiada też rzeczywistej dacie wykonania zdjęcia, T. Kwiatkowska, A. Malik, Zespół negatywów szklanych z zakładu fotograficznego rodziny Kriegerów..., s. 57.

13 J. Kozińs ki, Fotografia krakowska..., s. 107.

${ }^{14}$ T. Kwiatkowska, A. Malik, Zespót negatywów szklanych z zakładu fotograficznego rodziny Kriegerów..., s. 52-53 i 65.

15 Ibidem, s. 53.

${ }^{16}$ C. Bąk-Koczar s ka, Krieger Ignacy (1820-1889), w: PSB, t. 15, s. 307.

${ }_{17}$ Muzeum Krakowa, Natan Krieger (1844-1903), http://ignacykrieger.pl/?page_id=43 (dostęp: 26.03.2019). Zob. też: Album fotografii dawnego Krakowa z atelier Ignacego Kriegera, przedsłowie W. Bodnicki, oprac. J. Andruszkiewicz, Kraków 1989; J. Koziński, Fotografia krakowska..., s. 107; idem, Rodzina Kriegerów: krakowscy fotografowie dokumentaliści, „Alma Mater” 2015/2016, nr 180/181, s. 114-117.

${ }_{18}$ T. Kwiatkowska, A. Malik, Zespót negatywów szklanych z zakładu fotograficznego rodziny Kriegerów..., s. 53.

${ }_{19}$ M. Woźny, Początki Grona Konserwatorów Galicji Zachodniej w świetle krakowskich materiałów, „Rocznik Krakowski”, t. 77: 2011, s. 77-88.

${ }^{20}$ W Fototece Lanckorońskich znajduje się aktualnie 15 odbitek dotyczących kościoła Bożego Ciała w Bieczu. Część z nich sygnowana jest nazwiskiem Krieger, zob. m.in.: FL.2167.10, FL.2167.18, FL.2167.20. Ich obecność w zbiorze fotografii Karola Lanckorońskiego stanowi przejaw zainteresowania zabytkami Galicji jako jednej z prowincji Monarchii Austro-Węgierskiej. Karol Lanckoroński od roku 1910 był wiceprzewodniczącym Cesarsko-Królewskiej Centralnej Komisji do Badania i Zachowania Zabytków Sztuki i Historii (Zentralkommission für Erforschung und Erhaltung der Kunst- und historischen Denkmale). Zob. też J. Winiewicz-Wolska, Hrabia Karol Lanckoroński - kolekcjoner i mecenas, w: A. Korczyński, Fototeka Lanckorońskich, Lanckoroniana, t. 5, Rzym 2018, s. 7-8. 
kolekcjonerzy ${ }^{21}$. W gronie tych ostatnich znaleźli się Władysław Czartoryski22 i Karol Lanckoroński²3.

Wnętrza i wyposażenie kościołów chętnie były fotografowane przez Natana Kriegera ${ }^{24}$. Pochodząca z Zakładu Ignacego Kriegera dokumentacja fotograficzna $^{25}$ kościoła św. Katarzyny, którą Karol Lanckoroński zdecydował się umieścić w swoim zbiorze, wyodrębnia kilka kategorii tematycznych. Jedną z nich stanowi architektura kościoła ${ }^{26}$.

W tej grupie fotografii znajduje się widok kościoła św. Katarzyny ${ }^{27}$ od strony

${ }^{21}$ J. Koziński, Fotografia krakowska..., s. 107; E. Gaczoł, A. Kwiatek, Natan Krieger, Kraków 2018.

22 Władysław Czartoryski (1828-1894) zgromadził w Krakowie należące do jego rodziny zbiory, tworząc z nich w roku 1876 i uroczyście inaugurując w 1878, Muzeum Książąt Czartoryskich. Wspierał też rozwój działalności artystycznej oraz naukowej, w tym historycznej. Zob. też: M. Kukiel, Czartoryski Władysław, książe (1828-1894), w: PSB, t. 4, s. 300-303; E. Ga czoł, A. Kw iate k, Natan Krieger, Kraków 2018.

${ }^{23}$ Na prośbę Karola Lanckorońskiego wzmiankowane wyżej odbitki fotograficzne Biecza zamawiał u córki Ignacego Kriegera, Amalii Krieger, w 1915 roku Tadeusz Szydłowski, konserwator zabytków w Galicji Zachodniej (1914-1928); zob. A. Kor c zy ń s k i, Fototeka Lanckorońskich..., s. 59. Niewykluczone, że Karol Lanckoroński dysponował wykazem oferowanych zdjęć z Zakładu Ignacego Kriegera. O tym, że istniały takowe spisy i albumy-katalogi zaopatrzone w numery ewidencyjne oferowanych do sprzedaży zdjęć, zob. T. Kwiatkowska, A. Malik, Zespót negatywów szklanych z zakładu fotograficznego rodziny Kriegerów..., s. 52.

${ }^{24}$ T. Kwiatkowska, A. Malik, Zespół negatywów szklanych z zakładu fotograficznego rodziny Kriegerów..., s. 59.

${ }^{25} \mathrm{O}$ wartości dokumentacyjnej tych fotografii zob. m.in. M. N i e mi e c, ,, Jeden obraz zastępuje 1000 słów” - szklane klisze z zakładu Ignacego Kriegera..., s. 103-122.

${ }^{26} \mathrm{Nie}$ wchodząc w polemiki dotyczące tego zagadnienia, autor artykułu uznaje za stosowne przytoczyć w tym miejscu jedynie wybór literatury dotyczącej tematu: W. Łuszczkiewicz, Kościót Św. Katarzyny z klasztorem OO. Augustianów, Biblioteka Krakowska nr 8, Kraków 1898, s. 27-46; M. Kra s n o w ols k a, Z dziejów budowy zespolu augustiańskiego, „Rocznik Krakowski” 1976, nr 47, s. 23-44; W. Ko la k, Klasztor augustianów przy kościele św. Katarzyny w Krakowie do połowy XVI wieku. Fundacja, rozwój uposażenia i rola kulturalna, Kraków 1982, s. 65-70, 73-78; E. Chojecka, J. Samek, H. Małkiewi czówna, Kościót par. p. w. śś. Katarzyny i Małgorzaty..., s. 101-108; M. Szyma, Kilka uwag o architekturze kościoła św. Katarzyny na Kazimierzu, w: Mendykanci w średniowiecznym Krakowie, red. K. Ożóg, T. Gałuszka, A. Zajchowska. Studia i źródła Dominikańskiego Instytutu Historycznego w Krakowie, Kraków 2008, 4, s. 266-269; B. Krasnow olski, Restauracja zespołu augustiańskiego na Kazimierzu. Z dziejów ochrony krakowskich zabytków, Biblioteka Krakowska nr 152, Kraków 2010; J. Adamski, O genetycznej i chronologicznej zależności portali augustiańskiego kościoła św. Katarzyny na Kazimierzu w Krakowie i fary św. Elżbiety w Koszycach, „Folia Historiae Artium” Seria Nowa, R. 16: 2018, s. 35-61.

27 Spis widoków i pomników miasta Krakowa zdjętych z natury przez I. Kriegera wymienia kościół św. Katarzyny pod numerem 15 (wersja drukowana spisu) i 16 (wersja w rękopisie litografowanym). Zob.: J. Ko zińs ki, Fotografia krakowska..., s. 165, 170. Wyłącznie jednak w drugiej z wymienionych wersji Spisu wyszczególnione zostały ponadto cztery inne fotografie dotyczące architektury opisywanego kościoła i klasztoru: 147. Wschód do kościoła Św. Katarzyny, 150. Ramię wschodnie krużganku w kościele Św. Katarzyny, XIV w., 151. Widok kruchty od wschodu kościoła 
prezbiterium ${ }^{28}$ oraz część elewacji południowej ${ }^{29}$ wraz z kruchtą i portalem głównym $^{30}$. W Fototece Lanckorońskich znajdują się ponadto zdjęcia dokumentujące ówczesny stan zachowania portali ${ }^{31}$. Wyszczególnione fragmenty architektury kościoła, jak i część zabudowań klasztoru, w kontekście Fototeki Lanckorońskich stają się interesujące także $\mathrm{z}$ innego względu. Zostały one ufundowane m.in. przez antenatów twórcy fotograficznego zbioru, panów z Brzezia herbu Zadora ${ }^{32}$. Ich związek z klasztorem datowany jest od około roku $1420^{33}$.

Wnętrza pod względem architektonicznym dokumentują nie tylko fotografie krużganków klasztoru i sklepień krzyżowo-żebrowych ${ }^{34}$, ale także te obejmujące architekturę sepulkralną i towarzyszącą jej rzeźbę. W zbiorze fotografii Karola Lanckorońskiego są one reprezentowane przez dwa nagrobki. Jednym z nich jest znajdujący się w krużganku klasztoru renesansowy nagrobek zmarłego w roku 1580 radcy kazimierskiego, darczyńcy klasztoru i pisarza moralisty Jana Płoczywłosa Mrowińskiego ${ }^{35}$. Nagrobek ten przypisywany jest warsztatowi Hieronima

Św. Katarzyny, XV w., 153. Ganek klasztorny u XX. Augustianów z widokiem kościoła, zob. J. Kozińs ki, Fotografia krakowska..., s. 176.

${ }^{28}$ FL.2173.15.

${ }^{29}$ Fotografie: FL.2173.16, FL.2173.17, FL.2173.19.

30 FL.2173.18.

${ }^{31}$ Fotografie: FL.2173.20, FL.2173.21, FL.2173.22 i FL.2174.2 (portal wewnętrzny w nawie północnej). Zob. też: J. A d a mski, O genetycznej i chronologicznej zależności portali augustiańskiego kościoła św. Katarzyny..., s. 35-61.

${ }_{32}$ W. Łuszczkiewicz, Kościót Św. Katarzyny z klasztorem..., s. 15-17, 25. Władysław Łuszczkiewicz uwzględnia wśród dobrodziejów klasztoru m.in. Zbigniewa z Brzezia (zm. 1425). Zob. też A. Strze le c k a, Lanckoroński Zbigniew z Brzezia (zm. 1425), w: PSB, t. 16, s. 457-458; S. C y n a r s ki, Dzieje rodu Lanckorońskich z Brzezia od XIV do XVIII wieku. Sprawy kariery urzędniczej i awansu majątkowego, Warszawa-Kraków 1996, s. 78. Do grona fundatorów w tym okresie należeli też potomkowie Zbigniewa: Mikołaj i Jan. Zob. F. Kir y k, Lanckoroński Mikołaj z Brzezia (zm. 1462), w: PSB, t. 16, s. 446; S. C y n a r s ki, Dzieje rodu Lanckorońskich z Brzezia..., s. 92, 94. Szczegółowy opis darowizn Lanckorońskich na rzecz krakowskiego klasztoru augustianów, zob. W. Kolak, Klasztor augustianów przy kościele św. Katarzyny w Krakowie..., s. 32-35, 46-47, 58-59, 65; E. Chojecka, J. S a mek, H. Małki ewi czówna, Kościót par. p. w. śś. Katarzyny $i$ Matgorzaty..., s. 98-100. O fundacjach i o herbie Zadora w omawianym kontekście zob. też M. Kijewski, Średniowieczne programy heraldyczne kościoła św. Katarzyny i klasztoru augustianów na Kazimierzu, w: Coelo et Calamo. Studia epigraficzne i heraldyczne, red. W. Drelicharz, Kraków 2007, s. 19-39.

Ogólne informacje o początkach fundacji klasztoru augustianów z kościołem św. Katarzyny, zob. też: J. Wy ro zum sk i, Dzieje Krakowa. Kraków do schyłku wieków średnich, t. 1, Kraków 1992, s. $251-254$.

${ }^{33}$ W. Kolak, Klasztor augustianów przy kościele św. Katarzyny w Krakowie..., s. 68.

${ }^{34}$ Fotografie: FL.2174.1, FL.2174.3 i FL.2174.4.

${ }^{35}$ W. Łuszczkiewicz, Kościót Św. Katarzyny z klasztorem..., s. 79; J. Bieniarzówna, Mrowiński Jan (1514-1580), w: PSB, t. 22, s. 197. Fotografie: FL.410.16, FL.2174.10, FL.2174.11. Spis widoków i pomników miasta Krakowa zdjętych z natury przez I. Kriegera uwzględnia ów pomnik pod numerem 152. Zob. J. Ko zińs ki, Fotografia krakowska..., s. 176. 
Canavesiego i został ufundowany za życia Mrowińskiego, w roku $1577^{36}$. Drugi z nagrobków, wewnątrz kościoła, skrywa ciało zmarłego w roku 1568 kasztelana krakowskiego Wawrzyńca Spytka Jordana ${ }^{37}$. Zabytek dokumentują w zbiorze cztery fotografie ${ }^{38}$. Nagrobek Wawrzyńca Spytka Jordana, wykonany przez rzeźbiarza z kręgu Santiego Gucciego, powstał około roku $1603^{39}$ i zaliczany jest „ze względu na rozmiary, jak szlachetność form późnorenesansowych i bogactwo postaci portretowanych, [...] do najcelniejszych pomników odrodzenia w Polsce"40. Znajdujące się w Fototece Lanckorońskich fotografie nagrobka dokumentują jego stan po wykonaniu prac konserwatorskich w latach sześćdziesiątych XIX wieku, które miały miejsce z inicjatywy potomków Spytka oraz przy poparciu biskupa krakowskiego Ludwika Łętowskiego. Realizatorem prac był Edward Stehlik ${ }^{41}$. Postaci zmarłego fundatora, zgodnie z jego ostatnią wolą, towarzyszą rzeźby przedstawiające Mikołaja Jordana ${ }^{42}$ oraz Spytka z Jarosławia ${ }^{43}$. Niewykluczone jednak, że zdjęcia tego zabytku interesowały Karola Lanckorońskiego nie tylko ze względu na „szlachetność form późnorenesansowych”. Oprócz widocznych w głównej niszy wymienionych postaci w osobnych niszach rozstawione zostały cztery postacie kobiece $\mathrm{w}$ polskich szatach wdowich ${ }^{44}$. Jedna $\mathrm{z}$ nich przedstawia Jadwigę z Lanckorońskich ${ }^{45}$, której postać wieńczy herb Zadora (nisza górna

${ }^{36}$ E. Chojecka, J. Sa mek, H. Małkiewiczówna, Kościót par. p. w. śś. Katarzyny i Matgorzaty..., s. 127.

37 A. Ka mińs k i, Jordan Spytek Wawrzyniec z Zakliczyna h. Trąby (1518-1568), w: PSB, t. 11, s. $282-283$.

${ }^{38}$ Fotografie: FL.2174.7, FL.2174.8, FL.2174.9 i FL.2178.15. Spis widoków i pomników miasta Krakowa zdjętych z natury przez I. Kriegera uwzględnia ów pomnik pod numerem 86. Zob. J. Ko zińs ki, Fotografia krakowska..., s. 168 i 173.

${ }^{39}$ A. Kamiński, Jordan Spytek Wawrzyniec..., s. 282-283; E. Chojecka, J. Samek, H. Małki ewic zówna, Kościół par. p. w. śś. Katarzyny i Małgorzaty..., s. 112.

${ }^{40}$ W. Łu szc zki ew ic z, Kościót Św. Katarzyny z klasztorem..., s. 58. W tej samej nawie południowej kościoła św. Katarzyny już w roku 1507 spoczął Jan Jordan z Zakliczyna, kasztelan biecki i wielkorządca krakowski. W kościele tym spoczął również jego ojciec, Jordan z Zakliczyna. Żoną tego ostatniego była Jadwiga z Lanckorońskich (zob. FL.2178.15), córka Mikołaja Lanckorońskiego i wnuczka Zbigniewa z Brzezia. Informacje genealogiczne podaję za: W. Kolak, Klasztor augustianów przy kościele św. Katarzyny..., s. 56.

${ }^{41}$ E. Choje cka, J. Sa mek, H. Małkiewic zówna, Kościót par. p. w. śś. Katarzyny i Matgorzaty..., s. 112.

42 „Figury w grobie mają być ociec i dziad mój Pan Jarosławski”, cyt. za: W. Łu szczkiew i c z, Kościót Św. Katarzyny z klasztorem..., s. 57. Zob. też A. Ka miń s ki, Jordan Mikołaj z Zakliczyna h. Trąby (1467-1521), w: PSB, t. 11, s. 280-281.

${ }_{43}$ W. Dworzaczek, Jarostawski Spytek (Spytek z Jarostawia) h. Leliwa (ok. 1436-1519), w: PSB, t. 11, s. 6. Katalog zabytków sztuki w Polsce wymienia Jordana z Zakliczyna. Zob. E. C ho jecka, J. Samek, H. Małkiewiczówna, Kościót par. p. w. śś. Katarzyny i Małgorzaty..., s. 112. Zob. też przypis 42 .

${ }^{44}$ W. Łu s z c zk i ew i c z, Kościół Św. Katarzyny z klasztorem..., s. 59.

${ }^{45}$ Zob. przypis 40 . 
w prawej części nagrobka). W zbiorze Karola Lanckorońskiego zachowało się zdjęcie ukazujące zbliżenie jedynie tej właśnie postaci ${ }^{46}$. Pozostałe trzy postacie kobiece również zostały naznaczone herbami rodów, z których się wywodziły. Herb Leliwa występuje tutaj dwukrotnie: nad głową figury wyobrażającej żonę zmarłego, Annę Sieniawską (nisza dolna w prawej części nagrobka), a także nad głową matki zmarłego, Anny, córki Spytka Jarosławskiego (nisza górna w lewej części nagrobka). Pod herbem Rogala widoczna jest natomiast postać przedstawiająca pierwszą żonę ojca zmarłego fundatora, Katarzynę Pielgrzymowską (nisza dolna w lewej części nagrobka) ${ }^{47}$. Interesująca i bogata pozostaje również dokumentacja fotograficzna dotycząca artystycznego wyposażenia wnętrza kościoła.

Czołowymi dla kościoła św. Katarzyny zabytkami malarstwa były niewątpliwie fragmenty retabulum augustiańskiego oraz retabulum św. Jana Jałmużnika. Wzmiankowane dzieła znajdują się współcześnie w zbiorach Muzeum Narodowego w Krakowie, w Pałacu Biskupa Erazma Ciołka (Kanonicza 17). Dokumentacja fotograficzna przechowywana w Fototece Lanckorońskich PAU (Sławkowska 17), w zbiorze fotografii stworzonym przez potomka fundatora poliptyku św. Jana Jałmużnika, Karola Lanckorońskiego, wykonana została najpewniej jeszcze podczas stałego pobytu obrazów wewnątrz świątyni.

Fotografie poszczególnych scen z życia i męki Chrystusa z retabulum augustiańskiego, przypisywanego przez historyków sztuki ${ }^{48}$ krakowskiemu malarzowi Mikołajowi Haberschrackowi ${ }^{49}$, w zbiorze fotografii Karola Lanckorońskiego sygnowane są w większości nazwiskiem fotografa Ignacego Kriegera. Figurują też w Spisie widoków i pomników miasta Krakowa zdjętych z natury przez tegoż $\dot{z}^{50}$. W Fototece Lanckorońskich znajduje się jedenaście odbitek o tej tematyce (łącznie z dubletami) $)^{51}$. Trzy z nich nie posiadają wyraźnej sygnatury fotografa;

${ }^{46}$ FL. 2178.15.

47 W. Łuszczkiewicz, Kościót Św. Katarzyny z klasztorem..., s. 59.

${ }^{48}$ P. F rąc ze k i in., Retabulum Augustiańskie Nicolausa Haberschracka. Historia i stan zachowania dzieła - podsumowanie badań, „Rozprawy Muzeum Narodowego w Krakowie”, t. 8, 2015, s. 139-185; W. Marcinkowski, R. Klincewicz-Krupińska, Retabulum Augustiańskie Nicolausa Haberschracka (1468). Próba rekonstrukcji przepadlej struktury, w: Claritas et Consonantia. Funkcje, formy i znaczenia w sztuce średniowiecza. Księga poświęcona pamięci Kingi Szczepkowskiej-Naliwajek $w$ dziesiąta rocznicę śmierci, Toruń-Warszawa 2017, s. 253. Zob. też T. Dobrowolski, Sztuka Krakowa, Kraków 1971, s. 180; J. Gadomski, Gotyckie malarstwo tablicowe Małopolski 1460-1500, Warszawa 1988, s. 74, 139-140.

49 Przyjęta przez historyków sztuki atrybucja wzbudzała pewne archiwalne wątpliwości. Zob. W. Kolak, Klasztor augustianów przy kościele św. Katarzyny w Krakowie..., s. 78-82. O wcześniejszej kwestii autorstwa zob. też T. D o brow ols ki, Obrazy z życia i męki Pańskiej w kościele św. Katarzyny w Krakowie, Kraków 1929, s. 27-29.

${ }^{50}$ Spis widoków i pomników miasta Krakowa zdjętych z natury przez I. Kriegera uwzględnia pięć obrazów szkoły cechowej krakowskiej z XV wieku pod numerem 117. Nie wymienia jednak poszczególnych scen. Zob. J. Ko ziń s ki, Fotografia krakowska..., s. 175.

${ }^{51}$ Fotografie: od FL.410.2 do FL.410.6, a także od FL.413.22 do FL.413.27. 
na jednej została ona przycięta ${ }^{52}$. Pozostałych osiem odbitek jest sygnowanych: J. Krieger w Krakowie ${ }^{53}$.

Dystansując się od polemik na temat autorstwa i czasu powstania samego retabulum, można stwierdzić, że w zbiorze fotografii Karola Lanckorońskiego zachowała się dokumentacja fotograficzna fragmentów retabulum, które w kolejności wydarzeń biblijnych przedstawiają następujące sceny: Pokłon Trzech Króli ${ }^{54}$, Wjazd Chrystusa do Jerozolimy ${ }^{55}$, Jezus wypędzajacy przekupniów ze światyni ${ }^{56}$, Chrystus na Górze Oliwnej" ${ }^{57}$, Chrystus przed Kajfaszem ${ }^{58}$ i Chrystus przed Piła$t_{e m}{ }^{59}$. Dokumentacja fotograficzna poszczególnych fragmentów retabulum, mimo iż nie uwzględnia wszystkich zachowanych $\operatorname{scen}^{60}$, to i tak jest o jedną z nich liczniejsza aniżeli w przytoczonym Spisie widoków i pomników ${ }^{61}$. Nie zmienia to faktu, że na zespół jedenastu tablic, mieszczących trzynaście scen ${ }^{62}$, fotografie ze zbioru Karola Lanckorońskiego dokumentują jedynie sześć (w tym pięć scen powtarza się). Przez analogię z innymi tematami znajdującymi się w fotograficznym zbiorze Karola Lanckorońskiego można przyjąć, że starał się on dysponować możliwie pełną dokumentacją fotograficzną dotyczącą ołtarza augustiańskiego i to w kilku egzemplarzach ${ }^{63}$. Ołtarz, z którego pochodzą sfotografowane przez Kriegera fragmenty poszczególnych kwater, ostatecznie ustąpił miejsca barokowemu retabulum datowanemu na rok $1634^{64}$. Z czasem poszczególne tablice poprzedniego retabulum zawieszono w krużgankach klasztoru, gdzie miały następnie służyć jako stacje Drogi Krzyżowej. Po ich odrestaurowaniu zostały

${ }^{52}$ Fotografie: FL.413.24, a także FL.410.2 i FL.410.5.

${ }^{53}$ Mateusz Niemiec zauważa, że „Ignacy Krieger stał się marką. Odbitki fotograficzne wykonywane przez jego dzieci były sygnowane I. Krieger. Stąd fotografie Kriegerów, które zostały wykonane przez Natana i Amalię można spotkać w publikacjach i internecie z podpisami mówiącymi, iż daną fotografię wykonał Ignacy, choć ewidentnie zostały one zrobione już po jego śmierci”. Cyt.: M. N i e mi e c, ,Jeden obraz zastępuje 1000 stów” - szklane klisze z zakładu Ignacego Kriegera..., s. 107. Zob. też J. Kozińs ki, Fotografia krakowska..., s. 107; T. Kwiatkow ska, A. Malik, Zespót negatywów szklanych z zakładu fotograficznego rodziny Kriegerów..., s. 53 i 57.

${ }^{54}$ Fotografie: FL.410.2 i FL.413.22.

55 FL.413.24.

${ }^{56}$ Fotografie: FL.410.3 i FL.413.23.

${ }^{57}$ Fotografie: FL.410.4 i FL.413.25.

58 Fotografie: FL.410.5 i FL.413.26.

${ }^{59}$ Fotografie: FL.410.6 i FL.413.27.

${ }^{60}$ Najbliższe czasowo dokumentacji fotograficznej opracowanie Władysława Łuszczkiewicza wymienia jedenaście scen przypisywanych przez niego szkole cechowej malarstwa krakowskiego z XV stulecia. Zob. W. Łu s z c zk i e w i c z, Kościót Św. Katarzyny z klasztorem ..., s. 51-55.

${ }^{61}$ Zob. przypis 50 .

${ }^{62}$ J. Gadomski, Gotyckie malarstwo tablicowe Matopolski 1460-1500, Warszawa 1988, s. 138 .

${ }^{63}$ A. Korczyńs ki, Fototeka Lanckorońskich..., s. 100.

${ }^{64}$ W. Marcinkowski, R. Klincewicz-Krupińska, Retabulum Augustiańskie Nicolausa Haberschracka (1468). Próba rekonstrukcji..., s. 257. Zob. też fotografie: FL.2174.5 i FL.2174.6. 
zawieszone w prezbiterium kościoła, a następnie zakupione przez Muzeum Narodowe w Krakowie $(1936)^{65}$.

W Fototece Lanckorońskich znajduje się również wzmiankowana dokumentacja fotograficzna retabulum św. Jana Jałmużnika. Stanowi ją piętnaście odbitek fotograficznych z zakładu Ignacego Kriegera ${ }^{66}$. Fotografie te chronologicznie są najbliższe informacjom o retabulum św. Jana Jałmużnika przekazanym przez Władysława Łuszczkiewicza ${ }^{67}$. Dokumentują ówczesny stan zachowania oraz wygląd poliptyku i jego poszczególnych kwater. Retabulum zostało ufundowane około roku $1504^{68}$ lub $1502^{69}$ przez Mikołaja Lanckorońskiego ${ }^{70}$ dla krakowskiego klasztoru augustianów ${ }^{71}$. Współcześnie autorstwo przypisywane jest malarzowi określanemu mianem Mistrza Ołtarza św. Jana Jałmużnika ${ }^{72}$, ale i tu wcześniej występowały różne teorie na ten temat ${ }^{73}$. Od roku 1937 retabulum św. Jana Jałmużnika stanowi depozyt w zbiorach Muzeum Narodowego w Krakowie ${ }^{74}$ i obecnie również jest eksponowane w Pałacu Biskupa Erazma Ciołka.

Naczelne miejsce poliptyku zajmują naturalnie sceny z życia patriarchy aleksandryjskiego Jana Jałmużnika ${ }^{75}$. Zostały one jednak udokumentowane przez fotografa w układzie nieco odmiennym od eksponowanego współcześnie ${ }^{76}$. Poszczególne kwatery skrzydeł wewnętrznych (FL.410.13) układają się w następującej

${ }^{65}$ W. Marcinkowski, R. Klincewi c z-Krupińska, Retabulum Augustiańskie Nicolausa Haberschracka (1468). Próba rekonstrukcji..., s. 257-258.

${ }^{66}$ Fotografie: FL.409.1, FL.409.3, FL.409.24, od FL.410.7 do FL.410.15, FL.413.28, FL.413.29, FL.413.30. Spis widoków i pomników miasta Krakowa zdjętych z natury przez I. Kriegera pod numerem 155 wymienia Tryptyk z obrazami olejnymi z życia św. Jana Jatmużnika, pocz. XVI w., w kościele Św. Katarzyny, dziewięć zdjęć. Zob. J. Ko zińs ki, Fotografia krakowska..., s. 176.

${ }^{67}$ W. Łu s zc zki ew i c z, Kościót Św. Katarzyny z klasztorem ..., s. 26, 63-65, 67-71.

${ }^{68}$ Polemika dot. daty powstania ołtarza, zob. W. Kolak, Klasztor augustianów przy kościele św. Katarzyny w Krakowie..., s. 83.

${ }^{69}$ E. Chojecka, J. S a mek, H. Małkiewic zówna, Kościót par. p. w. śś. Katarzyny i Matgorzaty..., s. 114.

${ }^{70}$ Mikołaj Lanckoroński (zm. 1520) - cześnik sandomierski i burgrabia krakowski. W latach 1504 i 1505 pełnił funkcje szafarza poborów i skarbu koronnego oraz poborcy w ziemi krakowskiej. Sprawozdanie ze swej działalności złożył na sejmie w Radomiu 29 maja 1505. Zob. I. Kaniew s k a, Lanckoroński Mikołaj z Brzezia h. Zadora, w: PSB, t. 16, s. 446-448.

${ }^{71}$ E. Chojecka, J. S a mek, H. Małki ewiczówna, Kościót par. p. w. śś. Katarzyny i Matgorzaty..., s. 114; J. Ga d o m ski, Gotyckie malarstwo tablicowe Matopolski 1500-1540, Warszawa-Kraków 1995, s. 17.

${ }^{72}$ Zob. m.in. M. Otto-Michałowska, Gotyckie malarstwo tablicowe w Polsce, Warszawa 1982, il. 27.

${ }^{73}$ Zob. m.in. T. D obrow ols ki, Sztuka Krakowa, Kraków 1971, s. 185; W. Kolak, Klasztor augustianów przy kościele św. Katarzyny w Krakowie..., s. 83-85.

${ }^{74}$ E. Chojecka, J. S a mek, H. Małki ew ic zówna, Kościót par. p. w. śś. Katarzyny i Matgorzaty..., s. 114; J. Ga d o m ski, Gotyckie malarstwo tablicowe Matopolski 1500-1540..., s. 52.

75 J. Gad om sk i, Gotyckie malarstwo tablicowe Małopolski 1500-1540..., s. 31.

${ }^{76} \mathrm{O}$ strukturze cyklu legendy św. Jana Jałmużnika zob. m.in. K. Secomska, Krakowska legenda św. Jana Jatmużnika. Problemy stylu i warsztatu, „Folia Historiae Artium” 1991, t. 27, 
kolejności: Ocalenie okrętu (kwatera górna lewego skrzydła), Cud u grobu patriarchy (kwatera dolna lewego skrzydła), Dar wdowy (kwatera górna prawego skrzydła) i Usynowienie ubogiego młodzieńca (kwatera dolna prawego skrzydła). Kolejna z fotografii (FL.410.7) przedstawia natomiast Spór z patrycjuszem Niceta (kwatera górna) oraz Przyniesienie daniny z Afryki (kwatera dolna). Tak ułożonym kwaterom poliptyku ukazującym sceny z żywota św. Jana Jałmużnika towarzyszą w niezmiennym układzie sceny przedstawiające świętych anachoretów: $C u d$ św. Hilariona, Komunia św. Onufrego, Św. Marina i św. Maria Egipcjanka, a także Cud św. Symeona Stylity. W przypadku pełnego zamknięcia poliptyku niezmienione pozostają też sceny z żywotów św. Abrahama Syryjskiego i św. Eufraksji ${ }^{77}$. Władysław Łuszczkiewicz w roku 1898 zauważył, iż: „Rozrzucone części tryptyku skupione zostały i zestawione ponownie przed kilkunastu laty kosztem hr. Karola Lanckorońskiego, niepośledniego znawcy i miłośnika sztuki, który postarał się też o nader umiejętne ich odnowienie"78. W rękopiśmiennej spuściźnie Karola Lanckorońskiego w Wiedniu także zachowało się źródło wskazujące na jego bezpośrednie zainteresowanie zabytkowym kościołem św. Katarzyny w Krakowie oraz jego dofinansowaniem z pieniędzy rządowych ${ }^{79}$. Wykonana przez zakład Ignacego Kriegera dokumentacja fotograficzna retabulum św. Jana Jałmużnika ukazuje najpewniej poliptyk współczesny opisanemu przez Władysława Łuszczkiewicza ${ }^{80}$, a przy tym być może najbliższy swojemu pierwotnemu kształtowi ${ }^{81}$.

Zamykając ten krótki przegląd znajdującej się w zbiorze Karola Lanckorońskiego dokumentacji fotograficznej kościoła św. Katarzyny i klasztoru augustianów, pozostaje na koniec wymienić jeszcze dwie inne fotografie. Prezentują one kolejny, czwarty, jak przypuszczają historycy sztuki ${ }^{82}$, znajdujący się w prezbiterium kościoła siedemnastowieczny ołtarz główny ${ }^{83}$. Lata trzydzieste XVII wieku zapoczątkowały na podkrakowskim Kazimierzu okres ,snycerstwa monumental-

s. 104-106. Zob. też J. Gadomski, Gotyckie malarstwo tablicowe Małopolski 1500-1540..., s. $53-54$.

77 Zob. K. S e coms ka, Krakowska legenda św. Jana Jatmużnika..., s. 105, a także fotografia FL.410.15.

${ }^{78}$ W. Łus zc zki ewic z, Kościót Św. Katarzyny z klasztorem ..., s. 71.

${ }^{79}$ List Wilhelma von Hartla do Karola Lanckorońskiego, Wiedeń 11.09.1902, sygnatura 620/3-21. Zob. Karol Lanckoroński i jego spuścizna rękopiśmienna w zbiorach Austriackiej Biblioteki Narodowej, baza danych: http://projekty.viennapan.org/lanckoronski/index.jsp.

${ }^{80}$ W. Łu s zc zki ew i c z, Kościót Św. Katarzyny z klasztorem ..., s. 67-68.

${ }^{81}$ J. Ga dom s ki, Gotyckie malarstwo tablicowe Matopolski 1500-1540..., s. 53.

${ }^{82}$ E. Choj ecka, J. S a mek, H. Małkiew i zówna, Kościót par. p. w. śś. Katarzyny i Matgorzaty..., s. 108.

${ }^{83}$ Fotografie: FL.2174.5 i FL.2174.6. Spis widoków i pomników miasta Krakowa zdjętych z natury przez I. Kriegera pod numerem 87 uwzględnia Wielki ottarz w kościele Św. Katarzyny. Zob. J. Koziński, Fotografia krakowska..., Kraków 1978, s. 168 i 173; W. Łuszczkiewicz, Kościół Św. Katarzyny z klasztorem ..., s. 47-49. 
nego", a ołtarz główny kościoła św. Katarzyny jest tego przykładem. Twórców ołtarza upatruje się w kręgu warsztatu pracującego w tym czasie na zlecenie kanoników regularnych w kościele Bożego Ciała ${ }^{84}$. Widoczny na fotografiach ołtarz główny kościoła św. Katarzyny był odnawiany w okresie poprzedzającym wykonanie zdjęć (ok. 1852), ale i w okresie przybliżonym do ich realizacji (1865, ok. 1880 i 1888), a jego szczegółowy opis podaje Katalog zabytków sztuki w Polsce ${ }^{85}$.

Fotografie figurujące w Spisie widoków i pomników miasta Krakowa zdjętych z natury przez J. Kriegera, można było nabyć „w trzech formatach, tj. wielkim, gabinetowym i wizytowym"86. W zasobie Fototeki Lanckorońskich PAU znajdują się zdjęcia wielkoformatowe ${ }^{87}$. Posiadają one przybliżone wymiary odbitek $18 \times 26 \mathrm{~cm}$ oraz tekturek $28 \times 35 \mathrm{~cm}^{88}$.

Reasumując, dokumentacja fotograficzna w zbiorze Karola Lanckorońskiego liczy czterdzieści siedem wielkoformatowych odbitek albuminowych sygnowanych w większości nazwiskiem Ignacego Kriegera. Fotografie te przedstawiają między innymi stan kościoła św. Katarzyny i budynków klasztornych augustianów w Krakowie po przeprowadzeniu w nich części prac restauracyjnych w drugiej połowie wieku XIX. Tematyka fotografii jest charakterystyczna dla zbioru Karola Lanckorońskiego i obejmuje przede wszystkim: architekturę kościoła i klasztoru, architekturę i rzeźbę sepulkralną, malarstwo tablicowe oraz ołtarz główny, stanowiący przykład siedemnastowiecznego „snycerstwa monumentalnego”.

\title{
ADAM KORCZYŃSKI
}

\author{
THE PHOTOGRAPHIC DOCUMENTATION \\ OF ST CATHERINE'S CHURCH IN CRACOW \\ IN KAROL LANCKOROŃSKI'S COLLECTION OF PHOTOGRAPHS
}

Keywords: photography, Cracow, Krieger, Lanckoronski, art

\section{Summary}

A collection of photographs gathered by Karol Lanckoroński serves as a kind of photographic archive today. Because of the authorship of photographs kept there, this collection is not only of documentary, but also collector's and artistic value. Kept in the

\footnotetext{
${ }^{84}$ J. Bieniarzówna, J. M. Małe cki, Dzieje Krakowa. Kraków w wiekach XVI-XVIII, Kraków 1984, t. 2, s. 351.

${ }^{85}$ E. Chojecka, J. S a mek, H. Małki ewic zówna, Kościót par. p. w. śś. Katarzyny i Matgorzaty..., s. 108.

86 J. Kozińs ki, Fotografia krakowska ..., s. 168 i 177.

${ }^{87} \mathrm{O}$ różnorodności stosowanych w drugiej połowie XIX wieku formatów fotografii zob. m.in. Z. H a r a s m, Stare fotografie. Poradnik kolekcjonera, Warszawa 2005, s. 159 i 162.

${ }^{88}$ Szczegółowe wymiary konkretnych fotografii (podane w mm) uwzględnia Katalog zbiorów artystycznych i naukowych Polskiej Akademii Umiejętności: www.pauart.pl.
} 
Lanckoroński Phototheque of the Polish Academy of Arts and Sciences, this $19^{\text {th }}$-century photographic documentation contains, among others, photographs concerning St Catherine's Church and the Augustinians' monastery in the Cracow district of Kazimierz, as well as historic items and works of art connected with these sites. Most of the 47 identified thematic prints are signed with the surname Krieger.

Made in Ignacy Krieger's Studio, the photographic documentation of St Catherine's Church that Karol Lanckoroński decided to put in his collection separates a number of thematic categories that are its characteristic features: the architecture of the church and the monastery, sepulchral architecture and sculpture, panel painting and the main altar serving as an example of $17^{\text {th }}$-century "monumental woodcarving". Thus, the photographs described in the paper serve as interesting and valuable archive materials.

\section{АДАМ КОРЧИНЬСКИ (ADAM KORCZYŃSKI)}

\section{ФОТОДОКУМЕНТАЦИЯ ХРАМА СВЯТОЙ ЕКАТЕРИНЫ В КРАКОВЕ В СОБРАНИИ ФОТОГРАФИЙ КАРОЛЯ ЛЯНЦКОРОНСКОГО}

Ключевые слова: фотография, Краков, Кригер, Ланцкоронский, искусство

\section{Резюме}

Коллекция фотографий, собранных Каролем Лянцкоронским, в настоящее время является своего рода фотографическим архивом. В связи с авторством собранных в нем фотографий, эта коллекция обладает не только документационной, но и коллекционной и художественной ценностью. В этой фотографической документации девятнадцатого века, в Фототеке Лянцкоронских Польской академии знаний (PAU) в том числе находятся фотографии с изображением костела св. Екатерины, а также монастыря августинцев в краковском районе города, Казимеже, а также памятников старины и произведений искусства, связанных с этими объектами. Большинство среди сорока семи опознанных тематических снимков обозначено фамилией Кригер.

Фотодокументация из Студии Игнация Кригера, посвященная костелу св. Екатерины, которую Кароль Лянцкоронский решил поместить в своей коллекции, выделяет несколько так характерных для его собрания тематических категорий: архитектура костела и монастыря, погребальная архитектура и скульптуры, станковая живопись, а также главный алтарь, являющийся примером «монументальной резьбы по дереву» семнадцатого века. Можно с уверенностью утверждать, что представленные в статье фотографии являются интересным и ценным архивным материалом. 